\title{
Rosto e Mãos: Em torno de Deleuze, Derrida e Schiele
}

\begin{abstract}
"O ser começa entre as minhas mãos de homem. / o ser ,/ todas as mãos, / qualquer palavra que se diga no mundo, / o trabalho da tua morte, / Deus, que não trabalha. // Mas o não ser também começa entre as minhas mãos de homem. // O não-ser, / todas as mãos, / a palavra que se diz fora do mundo, / as férias da tua morte, / a fadiga de Deus, / a mãe que nunca terá filho, / meu não morrer ontem. // Mas as minhas mãos de homem onde começam?"

(Juarroz, 1998: 12)

Fernando Machado Silva Centro de Filosofia das Ciências da Universidade de Lisboa (CFCUL) fernandomachadosilva79@gmail.com
\end{abstract}

DOI 10.1515/kjps-2017-0006

\section{E a Questão Repõe-Se}

Retomamos, aqui, uma questão que ainda não perdeu, que nunca perderá, a sua pertinência, que nunca será respondida: o que nos faz ser humano? Será somente a ontologia que nos explica a singularidade que cada um é no mundo? E será essa singularidade partilhada? Disseminada numa multiplicidade? O que há em nós que nos faz ser o que somos, elevando-nos (e estaremos de facto?) tão acima do animal? Porque sabemos que esta performatividade - não questionamos a essência, o que é o humano, mas, propriamente, a insistência da existência, ou seja, o modo de um como que produz e é simultaneamente produzido o ente denominado como humano - não se decifra somente pela sua história evolutiva - que as análises, por exemplo, de Maturana e Varela em muito nos esclareceram em torno da diferença de grau e não de natureza entre 
o «homem» e o «animal»-, nem se exprime no uso peculiar e fantástico da razão. Tanto assim é que nada ainda se respondeu pela via ontológica, malgrado os belíssimos textos de Duns Scotus a Heidegger, por exemplo. Pelo que, este breve texto se faz a caminho ou fala de outra coisa, encaminha-se para um campo da filosofia que a partir da metade do século XVIII, conquistando finalmente um nome, se traduz por uma arte da analogia da razão, uma gnoseologia inferior, um conhecimento sensitivo, declarando, desde logo e infelizmente, essa cisão entre corpo e mente, sensação e razão.

Este texto enviesa-se pela via ético-estética. Não faremos uma arqueologia, nem tão pouco um tratado ontológico - vergamo-nos à nossa humildade. E ainda assim repetimos, batemos, ou antes, a pergunta repete-se, bate-se, rebate no pensamento, na dúvida, ao longo desta tentativa de cogitar, inquirir pela via inferior do conhecimento, pelo tactear sensitivo e sensível. Assim, estética, aqui, é entendida como aiesthesis e não um questionamento do belo por si, não é uma kalologia; a ética segue a definição deleuzo-foucauldiana de modo de existência, proveniente das suas leituras em torno de Espinosa (Deleuze) e dos Estóicos (Foucault, tal como se expressou na História da sexualidade e sequentes obras finais), contrariamente ao entendimento da ética como modo de conduta de um código de condução (moral). Pelo mesmo arroio cuja fonte ascende a Nietzsche, o humano, aqui, desvia-se do humanismo e dos processos de subjectivação modernos, sustidos e erigidos pela ideação de uma essência, para se pensar pela via da performatividade, de um fazer o humano ou outra forma-Homem - foi essa a morte anunciada por Foucault e entendida por Deleuze. Deste modo, o humano ou o homem, no presente texto, é um produto; e as formas de a-subjectivação críticas e desconstrutivas do homem, desmontando a ideação subjectivante e significante do humanismo moderno, não só são as ferramentas do desmantelamento dessa forma-Homem, como são, por sua vez, produtores de outros processos subjectivantes. Seremos demasiado ingénuos se não nos dermos conta que os discursos anti-humanistas e a-subjectivantes são, por sua vez, sujectivantes ou produtores de outra forma-Homem. Por outras palavras, a a-subjectivação é ainda sujeição e, arriscamos dizer, tudo o que pode ser dito, de molde construtivo ou desconstrutivo (no duplo sentido filosófico e 
não-filosófico), acerca do Homem, ou desta espécie que foi denominada de Homem, ou de humano, é ainda uma forma de Humanismo, não ao jeito da ideologia do lluminismo, mas por ser um discurso que se adiciona à epistéme inacabada porque de uma forma igualmente inacabada, portando uma outra ideologia, ou ideação. Mesmo as teorias trans- ou pós-humanas não elidem a sua ligação à forma-Homem; elas são, a seu modo, expressões de um humanismo, se entendermos e escutarmos nesse conceito um discurso que vai para lá do tempo histórico - porque decorre ainda hoje e agora neste momento - e procura, aliando disciplinas e pensamentos diversos e díspares, definir a espécie que somos. Só uma outra espécie submetendo-nos ao seu mundo pode acabar de vez com o humanismo.

Esboçamos, então, pela margem um percurso de reflexão. Desta forma, no centro da nossa reflexão, dois conceitos, dois traços far-se-ão guias, sugerindo a «origem» do que somos, de onde tudo se expande. São na verdade, cremos bem, os dois pontos de fuga do nosso ponto de vista, os dois pontos pelo qual se abriu o horizonte de possibilidades do ser homem, de ser humano, do fazer, da performatividade que veio a ser o humano: o rosto e a mão. O Homem é um rosto e uma mão, antes de ser uma linguagem, um pensamento; somos um certo rosto, uma certa mão que dá e acolhe, que produz a possibilidade de ser Homem. Rosto e mão são, antes de mais, duas formas ou dois modos de preensão do mundo e do outro, mas igualmente mais que preensão.

Assim, debruçar-nos-emos, primeiro, sobre a questão do rosto, através ainda de um certo tom humanista moderno, pela voz de Emmanuel Lévinas, talvez a última expressão digna e graciosa de criação de uma Ética - basta recordar o elogio de profunda tristeza escrito por Derrida para afirmarmos que a ética lévinasiana trata acima de tudo de dignidade humana. Centrando-nos na sua obra Totalidade e Infinito (1988), faremos uma leitura resumida das linhas de força do seu pensamento aí exposto em torno do Outro e da apresentação do Rosto para, de seguida, abordarmos o conceito de rostidade (visageité) de Deleuze-Guattari (1980). Relendo uma vez mais a obra de Lévinas e a sua proposta radical de um retiro egológico para o digno acolhimento do Outro, a questão de saber se um rosto já o é ou se é produzido, justamente por aquele que se coloca na posição desnivelada de o acolher, mantém-se indefin- 
ida. Procuraremos responder a essa pergunta, precisa e estranhamente, propondo a rostidade, enquanto conceito que configura o processo de subjectivação e significância de um corpo com a produção do rosto, como o processo de uma via negativa - uma que Lévinas talvez não concordasse - que se abre para a ética do filósofo franco-lituano. Por outras palavras, acolhe-se o Outro e o Rosto porque se o produz; a rostidade é, de certa maneira, um mecanismo que promove a Ética do Rosto de Lévinas, pelo que a critica de Deleuze e Guattari, de facto, é eficaz contra a «viragem ética». De seguida, questionaremos o conceito de mão, através Derrida/Heidegger (1990) e de Jean Brun (1991), de modo a pormos em fuga os dois pontos que supomos à sombra da anciã questão do homem. Terminamos procurando pô-los a vibrar, rosto e mão, na obra do pintor austríaco Egon Schiele com algumas breves notas.

\section{Rosto}

\subsection{Do Lado de Lévinas}

"A violência apenas pode visar um rosto."

(Lévinas, 2008, 204)

Lévinas define a Ética como filosofia primeira. Porém, mais do escrever uma Ética das éticas, a sua obra pode ser entendida como a procura do sentido da intersubjectividade e de um imediatismo vivido à luz da transcendência, da existência e do Outro (o humano e o todo Outro, radical). Dentro do pensamento fenomenológico para Lévinas não se tratou, pois, do visionamento de um outro que a mim se assemelha e me afecta, constituindo-o cognitivamente enquanto um meu alter ego, tal como foi formulado por Husserl, deixando aí ausente o elemento intersubjectivo da vida no seio de um universo socialmente partilhado.

Para Lévinas a consciência não era primeira nem principalmente a prática da redução e da representação da existência para nós mesmos, antes e inicialmente um acontecimento moral que reconhece e acolhe o já presente, estabelecido e inesgotável outro. Esse outro que partilha comigo o universo, chama-me, fala-me, dirige-se-me; e é este particular encontro, face-a-face, que é determinante para o filósofo, 
fundando a Ética. Na visão ética e social de Lévinas, casa e linguagem não tratam de questões de imposição, tomada e fundação, pelo contrário elas exemplificam como o «Eu» começa com a hospitalidade e reconhece o Outro, de tal maneira que o «Eu» se erige como uma despossessão primordial, uma primeira doação. Nenhum outro encontro tem um impacto tão devastador quanto o de uma outra pessoa. Por esse encontro, nesse encontro e nessa relação - que é sempre de força, segundo a lição de Foucault -, o «Eu» experiencia um chamamento, um prestar contas a si, para si e àquele que o chama, bem como deve dar resposta à ordem formulada pelo Outro sem mesmo a receber, como comando: «não matarás!». O comando ou mandamento é intrínseco à relação e é o que dá início, justamente pelo forçar de uma resposta, à linguagem como diálogo. Para Lévinas a origem da linguagem está, portanto, na resposta e não no endereçamento, na resposta ao outro, como retorno ao seu pedido, ao seu mandamento e nesse re-endereçar formula-se um diálogo. Dar resposta $a$ funda a responsabilidade, a qual é a experiência imediata e afectiva da transcendência, do infinito que é o outro, como também da fraternidade. No seguimento do diálogo, o qual prolongando-se pode decorrer como conversação ou ensinamento, o amigo que nos fala ou o mestre a quem escutamos, o traço como presença do outro em nós - atenua-se e do encontro depura-se a questão premente do sentido da justiça: é ela reparação dos erros? Équidade desinteressada? Ou o interesse do mais forte? E "[porque] a justiça é claramente as três coisas, constitui-se como uma espécie de pivot entre o mecanismo evidente no Ser e o gesto sobreerrogativo da responsabilidade" (Bergo, 2015).

No princípio está então a relação, a relação humana, ao invés do mundo ou de deus. Contudo, aquilo que é inerente, intrínseco à relação e a todos os encontros - e que só implicitamente Lévinas no-lo diz, ou desviando a nossa atenção para um dos seus elementos - é o diferencial de potência dos seus agentes. No instante do encontro, maioritariamente das ocasiões, há um elemento que age com um nível de potência superior ao outro e é na busca de uma homeostasia, por assim dizer, que o afectado retroage, como se seguindo as leis newtonianas da física. Ora, no princípio da relação ética lévinasiana, uma relação assimétrica, encontramos este mesmo caso, mas representado de modo mais intrin- 
cado: o «eu» deve promover em si um retiro egológico, dando-se início a esta relação com o pressuposto que «eu sou sempre mais forte que o outro» - a diferença de potencial está inicialmente viciada, uma vez que Lévinas deseja confrontar e eliminar o pressuposto criado, justamente, pela modernidade que afirmou o Eu e à qual ainda, Lévinas, pertence decorrendo daí o endereçar do mandamento prescrevendo o assassínio; mesmo se o retiro e o mandamento sejam simultâneos, ou o pedido clemente anterior ao retiro - retira-se o eu da sua casa, abrindo espaço, para hospedar o outro - o encontro está já viciado. Mas porque nos solicita e comanda o outro, ou porque escutamos um pedido e um comando? O encontro, concebido como uma «interrupção» na nossa temporalidade, é entendido como tal porque a percepção ou o visionamento do rosto do outro afecta-nos imediatamente, uma vez que este é primeiramente uma expressão. Esta interrupção é de extrema importância, pelo que nos conduz à noção de temporalidade e à transcendência, por um lado e, por outro, dar-nos-á mais informação para a nossa crítica.

O tempo, no pensamento do filósofo franco-lituano, consiste em dois eixos; um, seguindo a leitura husserliana da estrutura da consciência transcendental, caracterizado pelo fluxo da síntese de momentos de agora; o segundo, pontuado pelas interrupções entendidos como acontecimentos da transcendência. Uma interpretação possível de acontecimento ${ }^{1}$ seria o de uma força de tal potência que provocaria uma quebra geral na situação, uma força disruptiva abrindo um novo tempo no próprio tempo, ou que o faz saltar dos gonzos conduzindo o novo movimento das coisas, pelo que é preciso questionarmos como a transcendência, em Lévinas, é um acontecimento. Por um lado, para o filósofo a transcendência é, principalmente, relacional e fáctica e, por outro, o encontro com o outro, essa interrupção transcendente ou que nos abre à Transcendência, somente tem impacto na história ou deixa em nós um traço. A dificuldade surge, no entanto, pelo que entendemos por história, a qual é, em Lévinas, constituída por actos isolados ou ideações humanas (justiça, equidade, liberdade, etc.). Assim, a tran-

1 Ser-nos-ia impossível, aqui, realizar uma interpretação comparada do conceito de acontecimento com, por exemplo, Deleuze ou Derrida, pelo que não aprofundaremos mais do que o necessário para a leitura do Rosto em Lévinas e apresentamos as nossas mais sinceras desculpas. 
scendência irrompe do encontro - é relacional - e mantém uma relação circular com a vida profana - seu sentido fáctico -, porém, porque influi a cada vez no movimento temporal histórico do homem - a história, essa temporalidade ideada - levando-o a reavaliar as suas Ideias de acordo com uma interrupção que não podemos representar a nós próprios, a transcendência é tida e entendida como acontecimento. Por outras palavras, "transcendência entendida como a relação face-a-face vive do nosso prazer e desejo quotidiano, mesmo se os precede" (Bergo, 2015).

Estas dimensões do prazer e do desejo - um desejo, tal como em Deleuze, criativo e sem qualquer ligação à falta psicanalítica - fundam a própria existência humana, tida enquanto sensibilidade, ao invés de utilitária ou instrumentalista, negando ambas qualquer carácter solipsista no homem. Não só estamos, desde o nosso nascimento, mergulhados num mundo social, como somos constantemente, também desde o nascimento, confrontados, chocados pelas expressões dos outros, o seu vívido expressionismo. Mas, segundo o filósofo, esquecemo-nos deste impacte ou embate expressionista que nos forma, nos afecta produtivamente e encerramo-nos na nossa casa egoísta. Contudo, Lévinas afere que este desejo egoísta sucumbe na experiência do face-a-face, porque nesse encontro o rosto do outro não é um objecto mas uma pura expressão que nos afecta antes de qualquer raciocínio. É um acontecimento que nos leva a uma pré-história, por assim dizer, momento prévio a qualquer ideação que funda a história pelo comando e pedido nu e indefeso de um «não me mates!». Nudez desarmada que se acentua na escolha particular de personagens, mais do que alegóricas, que mascaram, por assim dizer, o rosto do outro: o órfão, a viúva, o estrangeiro.

Como se pode observar, a diferença de potencial da relação ainda mais se acentua porque o rosto do outro se dá a nós como o daquele a quem foi tirado qualquer coisa da existência, aquele que está marcado por uma falta afectiva na sua existência: o pai ou a mãe, o marido, a terra. Como nos esclarece a ensaísta Bettina Bergo, a nossa liberdade vê-se inflectida por uma resistência passiva que se transforma em vergonha:

A liberdade experimenta-se como imperial, injustificável; saindo assim de si, o «Eu" dá-se por culpado. Leva em consideração um outro, que é experimentado como «maior» 
que o «Eu» de duas maneiras: 1 ) a resistência passiva e a qualidade facial do rosto sustém o outro no exterior das estruturas de força e de conflito; 2) a «exigência» que o rosto me faz (descrito fenomenologicamente como «Eu») é inevitável, pelo menos na sua passagem. Assim, o «Eu» é individualizado pelo outro, extraído do seu contexto de interesses. "Trans-ascende», erguendo-se para o outro numa intencionalidade afectiva, que outras filosofias entenderam como sentimentos morais. (Bergo 2015).

A transcendência lévinasiana é, numa palavra, antropológica. Trata e rege-se de casos e experiências humanas; e o ser humano deve ser entendido como um ser constituído por relações com outros, intersubjectivas, enquanto constantemente, no seio de cada relação e no tempo próprio de cada relação, sofre particularizações e perdas egóicas. Cada um é, assim, pelas relações, imerso e emergindo delas, constituído afectivamente pelos outros e em todas as dimensões, no «exterior» e no «interior». Como dissemos, o encontro é assimétrico e viciado. A responsabilidade a mim pedida é não-negociável, uma vez que antes mesmo de «eu ser humano» faço já parte da humanidade e sou responsável por ela, mesmo que esteja à parte. O que o rosto lévinasiano propõe com o seu pedido, ou obrigatoriedade ética, é uma resposta que não pode ser mediada ou interpretada anteriormente por nós, previamente ao encontro e à aceitação da mensagem vinda do rosto do outro. O rosto obriga-nos a receber a ideia de infinito antes mesmo de desencadearmos qualquer operação cognitivista. Isto só é possível porque o encontro face-a-face funda a linguagem pois o rosto do outro é o primeiro traço de significação. O rosto do outro que nos olha traça, risca, marca em nós uma significação fundando a linguagem, significando a sua presença como uma existência pluralista e anterior a mim. Mas sendo assim, não é a relação primeira, pelo contrário, é o Outro. O outro que me atrai com o seu infinito inapreensível, incategorizável, incapturável, de impossível contenção, inabordável, impossível de possuir. Atrai-me e nessa atracção obsessiva sou feito refém, dominado por ele e criado para ele, sou submetido pela proximidade a uma relação assimétrica onde sou negado e me nego e me retiro perante a fraqueza que me tem refém. 
Há, como vimos, as personificações, ou máscaras dos outros: a viúva, o órfão, o estrangeiro; outros fragilizados na sua existência, máscaras que fragilizam ainda mais o projecto de Lévinas. Problema observável justamente no entendimento da hospitalidade e da casa que hospeda, cuja moral condutora é personalizada com a Mulher ou a Esposa. O outro, assim caracterizado, acolhe-nos com intimidade, dotado de uma alteridade feminina - diríamos assombrada por uma ideação da essência do Feminino, do que é o Feminino -, localizada para lá da linguagem, numa outra dimensão, demonstra, com o seu comportamento, uma discrição ou uma reserva envolta em silêncio (essa dimensão para lá da linguagem). Ou seja, outro concebido, uma vez mais e implicitamente, como frágil ou uma criada de quarto presente para apoiar o esforço masculino na sua expressão (qualquer que ela seja). O outro, personificado imediatamente como Feminino, parece surgir para desequilibrar e tornar ainda mais dramático o encontro do face-a-face; ao dar-se para a relação, a presentificar-se com a sua solicitação ou mandamento, serve a possibilidade da relação e do surgir da linguagem a partir de um lugar de silêncio ou exterior à linguagem. (Poderá ser bruta a nossa crítica às personificações de Lévinas, mas preferimos a defesa da vida impersonificada, que engloba a flora, a fauna, a água, o ar, a terra; a esses ensurdecemo-nos ao seu mandamento).

Como pode, então, haver nudez quando o próprio Lévinas diz estar presente no rosto uma concentração dos sentidos superiores, os factores da comunicação e da relação intersubjectiva? Quando o rosto oculta um mistério que tem de ser desvelado? Nesta relação do Eu-Outro face-a-face, em que o eu se coloca ou abre em si o ser-para-o-outro, não cairemos numa tautologia, numa absoluta passividade, em vez de resistência passiva, em que o Outro que se coloca no face-a-face se dá como EuOutro igualmente procedendo ao apagamento egológico que o EuOutro? Também no pressuposto da linguagem como sendo comunicativa o projecto lévinasiano encontra alguns paradoxos quando, por exemplo, afirma que pela linguagem ofereço coisas minhas a outrem: só posso oferecer se possuir, se estabelecer uma propriedade para dizer que ofereço coisas minhas, mas em oferecendo não estou, simultaneamente, a afirmar a presença de um ego proprietário que deve estar ausente ou retirado para acolher e oferecer a sua casa, a sua propriedade? 
Se o rosto, enquanto primeiro discurso, é tal que obriga a entrar no discurso, essa imposição não nos cala? Não expressa a falta de comunicação, ou nos diz que a linguagem é uma forma de poder que obriga? E não temos de calar o outro, nem que seja por breves momentos, para que se possa falar ou ter a palavra no discurso? São estas questões críticas que nos fazem ligar ao projecto ético de Lévinas a crítica ferocíssima de Deleuze-Guattari, como o seu gémeo monstruoso Mr. Hyde. O outro rostifica-me enquanto me mantém seu refém, ele marca em mim traços de significação e de subjectividade; e é um rosto como o dele que é produzido em mim, um rosto como o dele para que o possa reconhecer. Por outras palavras, no encontro face-a-face, antes mesmo de surgir a linguagem, tem de surgir em nós, enquanto Eu presente a um Outro, um rosto que seja o rosto-do-outro para esse Outro, tem de haver o traço de significação e de subjectividade no muro branco-buraco negro. A rostidade derruba o projecto lévinasiano e simultaneamente demonstra o poder da representação que a arte recupera a sua vertente mimética.

\subsection{Do Lado de Deleuze-Guattari}

Poder-se-ia construir uma história do homem tomando apenas como elementos estruturantes e narrativos os regimes semióticos. Aliás, o princípio dessa hipótese já se esboçou no terceiro capítulo, Selvagens, Bárbaros, Civilizados de Anti-Édipo ${ }^{2}$, tendo o seu prosseguimento em Mil Platôs, no capítulo quinto, 587 A.C. - 70 D.C. Sobre alguns regimes de Signos $^{3}$. Ora, a mudança de regime semiótico implica uma nova percepção do que é um corpo, o que implica uma relação de forças, tocar e ser tocado, ver e ser visto, etc. Assim, segundo José Gil, percepcionar significa "sofrer uma esquiva e compensá-la com um equívoco" (1997, 148). Porquê esquiva e equívoco? Em presença frente a alguém, nunca podemos ver realmente o que o outro experiencia, podemos somente identificar certas expressões, olhares, gestos, palavras, mas nunca entrar e ver a experiência do outro. A experiência do outro furta-se-nos, uma vez que é a nossa ausência no aqui e agora do instante ocupado pelo

2 Vd. Deleuze e Guattari, 1973, 163-324.

3 Vd. Id., 1980, 140-184. E também, embora quase todo Mil Platôs, pela sua forma rizomática, circule por diversos temas, o capítulo 12. Tratado de Nomadologia: A máquina de Guerra, 434-527. 
outro, a sua presença indica a nossa ausência aí onde ele experiencia. A comunicação do acontecimento dá-se no e pelo contacto ${ }^{4}$.

Mas tudo o que se passa no «interior» do outro esquiva-se-nos, nunca podemos efectivamente perceber, ou conceber, o que se passa senão por um equívoco, por suposições, ou tomar o exterior pelo interior, o que, de acordo com Gil, implica a construção de um «interior» outro do outro. Esta relação no seio da percepção é semelhante à relação interior no signo, uma vez que "a relação do signo, ou relação semiótica, começa por um equívoco: os sinais exteriores, as «indicações», são tomados pela coisa mesmo. Ou seja, pelo interior, pela emoção, sentimentos, pensamento vividos. A expressão é tomada pelo expresso" (1997, 149).

De acordo com Deleuze-Guattari e Gil, a concretização de uma subjectivação faz-se através da máquina abstracta rostidade (visagéité). Esta máquina coordena-se a partir de dois dispositivos, muro branco-buraco negro, que correspondem à relação significância/subjectivação das componentes das palavras de ordem. Porquê palavras de ordem? É que a língua é, acima de tudo, uma instituição de poder, do poder. A língua institui-se por uma centralização, uma homogeneização, uma padronização dos múltiplos agenciamentos de enunciação tornando-se como um enorme território ${ }^{5}$. Esses agenciamentos, como o Ser para os Estóicos, compõem-se de misturas de corpos e transformações incorporais e Deleuze e Guattari identificam-nos, respectivamente, como conteúdos e expressões ${ }^{6}$. Estes conceitos indicam duas formas independentes entre elas. As expressões não representam os conteúdos, intervém sobre estes, inserem-se nos conteúdos e, por sua vez, os conteúdos na expressão. Os conteúdos, ligados à ideia de mistura de corpos, apresentam a forma "mão-ferramenta, ou a lição das coisas" $(1980,109)$; enquanto as expressões, as transformações corporais, formalizam-se

$4 \quad$ Gil, 1997: 148. “ (...) «comunicar» com outrem é entrar em contacto, misturar substâncias. Qualquer que seja a maneira como se pensa este "comunicar», ele implica um contacto directo que é, ao mesmo tempo, conhecimento e afecto".

5 Deleuze e Guattari, 1980, 128. "L'unité d'une langue est d'abord politique. II n'y a pas de langue-mère, mais prise de pouvoir par une langue dominante, qui tantôt avance sur un large front, et tantôt s'abat simultanément sur des centres divers".

6 Estamos, de facto, perante os conceitos de Louis Hjelmslev, contudo ganham contornos ligeiramente diferentes dos compreendidos pelo linguista dinamarquês. 
como "rosto-linguagem, a lição dos signos" (1980, 109). Tanto a lição das coisas como a lição dos signos referem-se aos corpos, aos corpos agidos e aos corpos ditos ${ }^{7}$.

Lição dos signos. Os rostos não começam por ser individuados, principiam ao invés por ser uma frequência de expressões, um campo de traços ordenados que reduzem as significações que escapam a um regime semiótico. Formam um lugar onde ressoam as sensações, onde ressoa "o real mental ou sentido, tornando-o antecipadamente conforme a uma realidade dominante [isto é, um regime semiótico]" $(1980,206)$. O rosto forma-se ou esboça-se, deste modo, a partir de um muro - folha, tela - onde os significantes chocam, passam, arranham; e um buraco por onde escoam, se coam, se filtram as percepções e os afectos. A máquina abstracta, uma máquina social técnica, produz e regulamenta um regime semiótico que irá dar um significante a um muro branco e uma subjectividade a um buraco negro. Mas porquê o rosto e não o corpo? Não será o corpo, na sua dimensão, nas suas possibilidades de movimentos expressivos, em toda a sua complexidade mais adequado a fornecer o lugar de um muro branco-buraco negro?

De acordo com Deleuze e Guattari não, devido a uma distinção de sistemas a que os rostos e os corpos estão submetidos. O rosto integra-se num sistema superfície-buracos, enquanto o corpo num sistema volume-concavidade ao qual a cabeça se integra. O rosto é uma superfície com marcas, rugas, traços de expressão, espaço geométrico (rosto triangular, oval, redondo, quadrado) envolvendo buracos (olhos, boca, narinas). Mas o rosto só se forma quando a cabeça se desliga do corpo, quando começa a ser regida por outro código que não o do corpo, o código Rosto da máquina abstracta rostidade. Desligando-se a cabeça enquanto rosto arrasta os volumes-concavidades até torná-los buracos numa superfície. Tudo começa com uma desterritorialização (No princípio era o movimento) ${ }^{8}$.

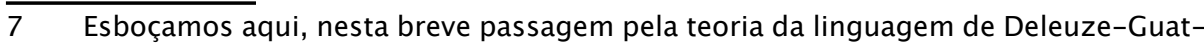
tari, um dos motivos porque aliamos neste texto o rosto e a mão. Não o fizemos no passo anterior com Lévinas, onde a mão também tem certa presença, por nos parecer mais importante o pensamento do filósofo em torno do rosto.

8 Será por essa razão que o prefácio de Movimento total, livro sobre o corpo e dança de Gil abre com essa frase? Porque a verdade é que antes de falarmos, de emitirmos 
A desterritorialização implica quatro teoremas: 1) a desterritorialização é sempre de dois termos e cada um deles se reterritorializa sobre o outro (mão-ferramenta, boca-seio, rosto-paisagem, etc.); 2 ) cada termo da desterritorialização tem diferentes velocidades e intensidades; e a velocidade/intensidade de desterritorialização não deve ser confundida com as do desenvolvimento: o que resulta que uma desterritorialização mais lenta mas mais intensa pode recolher uma outra na sua reterritorialização (daí a boca-seio inserir-se na rostoidade); 3) o termo menos desterritorializado reterritorializa-se sobre o mais desterritorializado, isto é, regra geral, as que são relativas reterritorializam-se nas absolutas (razão pela qual o rosto arrasta o corpo na sua rostoidade) e 4) "a máquina abstracta não se efectua apenas nos rostos que produz, mas, em diversos graus, nas partes do corpo, nas roupas, nos objectos que ela rostifica segundo uma ordem das razões (não uma organização de semelhanças)" (1980, 215).

O conceito de rostidade, assim exposto, representa também a separação entre povos «primitivos» e «desenvolvidos», ou seja, diferentes regimes semióticos. A relação que os «primitivos» têm com o corpo e a sua sociedade, a sua cultura e natureza, bem como a possibilidade de serem preenchidos/possuídos por energias exteriores em rituais (os devires animais) não lhes confere a necessidade de terem um rosto. Por outro lado, num regime que inaugura um corpo próprio, a individualidade, necessita da produção de rostos:

Trata-se de uma abolição organizada do corpo e das coordenadas corporais pelas quais passavam as semióticas polívocas ou multidimensionais. Os corpos serão disciplinados, a corporeidade será desfeita, promover-se-á a caça aos devires-animais, levar-se-á a desterritorialização a um novo limiar, já que se saltará dos estratos orgânicos aos estratos de significância e de subjectivação. Produzir-se-á uma única substância de expressão. (1980, 221-222).

qualquer som, o que acontece é o movimento de forças, o arrombamento de um sopro, a animação de um movimento interior que leva a um grito. 
É pois, acima de tudo, pelo rosto, como entrada de subjectivação e choque de significância, que temos acesso ao outro e que adquirimos igualmente um rosto. Não se trata de um reflexo de espelho, mas antes como que uma equivalência, como um jogo de pergunta-resposta, em que um envia signos de significância e subjectivação e recebe a «resposta» com os traços do outro ${ }^{9}$. Os traços do rosto são os traços da paisagem interior, das forças que o animam, das energias que o percorrem, dos afectos e das percepções marcadas. Quando se estabelece a relação ver e ser visto, o olhar não se prende ao exterior, penetra para lá da pele pelos buracos negros que são os olhos, o que torna o rosto a entrada principal de qualquer indivíduo. E da mesma forma que não temos apenas uma língua ${ }^{10}$, também não temos somente um rosto. Ele, o rosto, é instável, depende das experiências, dos encontros, mas esses outros rostos partem de ou terminam em um só: o rosto (do) Homem branco, o rosto de Deus ${ }^{11}$.

Deleuze e Guattari têm razão. Que rosto se projecta sobre todos os outros rostos senão o do Homem branco? Quando há o exercício de uma força, quando há força, há uma outra que se lhe opõe. Quando Deleuze e Guattari afirmam a homogeneização de cada rosto, falam exactamente da acção imensa de uma força de subjectivação, ou seja, uma força que sujeita cada traço individuante de um rosto, cada linha que, colado um rosto a outro, se desvia da norma. O grande rosto do Homem branco é bem a expressão normativa de uma força subjectivante, modela cada traço, disciplina um padrão regulador, sujeita cada rosto a um Mesmo. Ora, se esse rosto é uma força, ele age sobre outra força já constituída, tal como toda a acção subjectivante formadora de uma subjectividade

9 Gil, 1997, 169-170. "O meu rosto é-me significado indirectamente, através de pequenas percepções refractadas nos rostos dos outros. Sem os outros eu não teria rosto. Mas o rosto que tenho, e que nunca vejo, depende do processo de significância e de subjectivação que o sistema buraco negro/muro branco dos rostos dos outros induzem em mim".

10 Vd. Derrida, 1996, 23. "1. On ne parle jamais qu'une seule langue - ou plutôt un seul idiome. 2. On ne parle jamais une seule langue - ou plutôt il n'y a pas d'idiome pur.". Itálico do autor.

11 Deleuze e Guattari, 1980, 216. "Le visage n'est pas un universel. Ce n 'est même pas celui de I 'homme blanc, c'est l'Homme blanc lui-même, avec ses larges joues blanches et le trou noir des yeux. Le visage, c 'est le Christ". 
nada mais é do que a anulação de uma pré-subjectividade constituindo-se, a normalização de uma a-normalidade, uma anomalia.

Dois elementos constituintes da Natureza, percorrendo todos os seus reinos, do microscópico ao macroscópico, travam uma batalha incansável. Os seus nomes são, por exemplo, ordem e caos, mas também poderiam ser ditos mimésis e poiésis, que melhormente exprimem a verdadeira batalha configuradora do mundo. Mas tomando ainda de empréstimo a ordem e o caos, como as duas forças elementares, desviamos para a dimensão da primeira a mimésis, e para o segundo a poiésis, sabendo, todavia, que não existe nenhuma pureza nos conceitos, no modo como cada um exerce a sua função configurante. Ou seja, entre uma e outra, entre a mimésis e a poiésis, subsiste e insiste um diálogo, cada uma infecta a dimensão da outra. Não há mimésis sem uma certa invenção e não há invenção sem um traço mimético, como se aí se jogasse o tema ontológico da dissertação de Deleuze, a repetição (mimésis) e a diferença (poiésis). Cada rosto, como acima dissemos, é percorrido por forças expressivas e sensações, traços, marcas, rugas, esgares, vibrações. Todo o rosto pulsa, se encontra em construção. Por um lado, sobre esse ecrã do par muro buraco/buraco negro a poiésis procura, através da conjugação das significações e sensações, através da preensão das significações e sensações, construir um rosto na cabeça, um rosto único, singular, de cada um; por outro lado, igualmente sobre essa superfície - tudo se passa na profundeza dessa superfície - a mimésis ordena, re-ordena, normaliza, padroniza todos esses traços, agrupa sensações indicando as significações que se devem formar, re-presentar no rosto. Tomemos, como exemplo, um sorriso: um pai ou uma mãe, no furor da alegria do recém-nascido, envia signos expressivos, um movimento de músculos com uma significação vibrante de emoção, todo o seu rosto se torna uma paisagem (um percepto) plena de um traço emotivo (um afecto). Esse rosto projecta-se na superfície, no ecrã «pré-rosto» da criança (na verdade, se toda a nossa atenção se prender nesse projecto de rosto que é a face do bebé, percebemos toda a acção dessas duas forças, da poiésis e da mimésis; o seu rosto é constantemente percorrido por esgares, por tremores, espasmos) que imediatamente responde com a imitação do sorriso que se Ihe apresenta; e conquanto haja imi- 
tação do sorriso do outro, cada sorriso inventa a sua especificidade, a sua singularidade.

Humano demasiado humano? Sempre achei estranho esse título da obra de Nietzsche e sempre o tomei como um dos exemplos da ironia do pensador alemão. Não, o homem ainda não se cumpriu. Pois como disse o poeta António José Forte, colhendo a Cesariny, "enquanto um homem, um só que seja, e ainda que seja o último, existir desfigurado, não haverá figura humana sobre a terra" (Forte, 1989, 101). O rosto é uma enorme violência, como também um poder e onde simultaneamente se revela um modo de contra-poder. Na verdade, podemos deduzir, a partir de Lévinas, o rosto de Outrem como a Lei ${ }^{12}$ e esse rosto conclusivo de Deleuze e Guattari apresenta-se, contundentemente, como essa Lei. Este desfiguramento do rosto, apontado por António José Forte, deve ser levado à letra. O desfiguramento do rosto descobre-se na violência da letra que fere, da letra da Lei figurada na grande máquina-Rosto e que configura cada rosto. Talvez seja humano a luta contra o tempo, o adiamento da morte, a ocultação da natureza. Talvez seja expressão pura do humano demasiado humano a homogeneização do rosto, da subjectividade, a construção de uma ilusão, de uma aparência. À Lei violenta do rosto do Homem branco, junta-se a adenda do sempre jovem, um outro desfiguramento do rosto humano.

Cada rosto está sujeito à força da intemporalidade do «Belo». O Belo, como grande ideal, ao contrário de uma vida, não esmorece, não definha, não morre. Todavia, cada rosto é uma expressão do Belo, cada rosto é uma peça do mosaico do Belo. O rosto é a manifestação da expressão de uma vida que nunca, na verdade, revela o seu verdadeiro rosto. $O$ rosto que oferecemos a ver, a perscrutar, a mergulhar ao outro, é sempre uma expressão, uma aparência de um rosto nunca terminado, ou como diz Lévinas:

A expressão não irradia como um esplendor que se espalha do desconhecimento do ser irradiante, o que é talvez a definição da beleza. Manifestar-se assistindo à sua man-

12 Lévinas, 1988, 193. "Esse infinito, mais forte do que o assassínio, resiste-nos já no seu rosto, é o seu rosto, é a expressão original, é a primeira palavra: «não cometerás assassínio»". Sublinhado do autor. 
ifestação equivale a invocar o interlocutor e a expor-se à sua resposta. A expressão não se impõe nem como uma representação verdadeira, nem como um acto. O ser oferecido na representação verdadeira continua a ser possibilidade de aparência. (ibid.: 194).

Rosto como espaço de exercício de poder e contra-poder. Eis aí a acção da mimésis e da poiésis, confundindo-se uma à outra na configuração de um rosto. Enquanto a mimésis oferece um rosto para o reconhecimento, a poiésis age de modo a libertar as linhas de fuga do rosto, forçando sobre a aparência a potência latente de cada rosto, oferecendo um rosto a conhecer. Daí que, igualmente, cada rosto se mostra como a encarnação de um Unheimliche. O que há de estranhamente familiar num rosto é a vibração da força poiética procurando irromper a máscara mimética. E onde, de forma exemplar, se descobre ou se dá esse rompimento é na arte.

\section{Mãos}

"E, coisa estranha, apesar disso essas mãos que no palco adquiriam uma beleza quase inquietante, nos meus joelhos eram apenas umas mãos banais."

(Tanizaki, 1999, 41)

Será assim tão estranho num estudo subordinado à Estética, como este texto, todo o pensamento se vergar ao peso de questões ontológicas? Tendo Baumgarten definido a Estética como uma gnoseologia - inferior, é certo - não podemos evitar a inquirição do Ser. Ser é sempre ser qualquer coisa e a Arte dá a ver o Ser, interroga o Ser pela Imagem.

Ora, como Louis Marin nos mostra, a imagem é uma species ${ }^{13}$ de visibilidade. O pensamento Ocidental sempre respondeu à questão "o que é a

13 Igualmente Agamben infere como uma das características da imagem o ser uma espécie, demonstrando etimologicamente o termo species (aparência, aspecto, visão, significando também, olhar, ver, ligando-se ainda a speciosus, belo) e concluindo deste modo: "A imagem é um ser cuja essência é ser uma espécie, uma visibilidade ou uma 
imagem?" significando-a como uma categoria, ou seja, tornou a imagem num modo de ser, um decalque, uma cópia.

Quando o ser da imagem é tomado como um dos seus modos, logo alguma coisa é subtraída à imagem, a imagem é traída na sua «essência». E essa traição é a redução da imagem à condição de cópia, a um segundo grau de qualquer coisa, a aparência de estado que engana a relação intrínseca entre ser e imagem, sob as regras da imitação, torna-se um duplo, ecrã de projecção do ser, representação e substituição do ser. De acordo com Marin, a questão do ser é respondida por uma "defecção ontológica na ordem do conhecimento" (Marin, 1993, 10). Ou seja, não o que é a imagem mas no que ela se assemelha ao ser, o que ela nos dá a conhecer do ser ou mesmo o que nos impede de conhecer. Por essa razão o filósofo francês propõe, não a redução da imagem à categoria de mimema nem o reenvio ao próprio ser mas, a interrogação das forças latentes ou manifestas, a eficácia, na palavra de Marin, da imagem: o ser da imagem é a sua força. A imagem é, pois, mais do que re-presentação - no sentido em que Marin pensa a representação, como marca e reforço da "ausência do «mesmo»" (1993, 11), a imagem instaura, marca a ausência no tempo e no espaço ou dá lugar a um outro através da substituição - é captura das forças que percorrem o Ser; e é exactamente por ser captura, preensão, que se pode falar de ausência do «mesmo». Ao Ser, a cada ser, a cada ente, roubamos, como descendentes de Prometeu que somos, o seu fogo, as suas forças, parte das suas forças.

Ora, não só é inevitável um discurso que se preenche de tons ontologistas, como são chamados à presença as forças e o corpo. A particularidade destes discursos descobre-se no uso de certos verbos que remetem para um conceito que temos vindo a sublinhar: a preensão. Quer se trate do Ser, das suas forças, da representação do Ser através das forças presentes embora invisíveis, ou mesmo de efeitos na e da sensação, encontramos termos como captura, pressão, agarrar, prender, possuir, largar, que apontam (mais outro termo) para um membro muito específico do corpo, a mão.

aparência. Especial é o ser cuja essência coincide com o seu dar-se a ver, com a sua espécie." (Agamben, 2006, 78). 


\subsection{Do Lado de Derrida/Heidegger}

O ensaio de Derrida, cujo título é La main de Heidegger, incluído num conjunto de textos provenientes de conferências e trabalhados posteriormente para o volume Heidegger et la question, corresponde ao desenvolvimento de uma investigação sobre o problemático conceito alemão Geschlecht, bem como a questão do Ser, do signo, da monstruosidade, de e em Heidegger. A problemática desse conceito surgiu a Derrida no âmbito de um dos seus seminários, Nacionalidade e nacionalismo filosóficos, quando, na leitura da tradução francesa do sétimo Discurso à nação alemã de Fichte, o filósofo franco-argelino se dá conta da sua omissão. Como de imediato nos informa, o conceito Geschlecht não tem um significado simples e, dependendo do contexto, poderá ser traduzido por "sexo, raça, espécie, género, tronco [ou cepa] (souche), família, geração ou genealogia, comunidade" (Derrida, 1990, 176). ${ }^{14}$ A sua supressão na tradução francesa, tendo sido realizada após a segunda grande guerra, demonstra bem a influência político-social da época ainda fragilizada e que "tornaram a palavra raça particularmente perigosa e impertinente para a tradução de Fichte" (1990, 177). Todavia, Derrida informa que, embora Geschlecht se alie à questão da nacionalidade, o nacionalismo predicado por Fichte encontra-se entranhado por um cosmopolitismo, indo o conceito para além do significado de um tronco único de um país, transformando-se ao invés numa imensa raiz, um "nós" 15 verdadeiramente plural indicando dois outros conceitos que, conquanto de origens linguísticas diferentes, apontam a mesma união do Homem: Menschlichkeit (termo do antigo alemão) e Humanität (de ascendência latina) (1990, 177-179). De imediato o filósofo desconstrutivista nos alerta para a relação que se estabelece entre o discurso fichteano e os textos sobre a linguagem de Heidegger, relação essa partilhada por um dos sentidos de Geschlecht, aquele que retoma o termo antigo alemão.

14 As citações do texto de Derrida são traduções nossas.

15 Derrida, 1990, 178: "O Geschlecht é um conjunto, uma reunião [rassemblement] (poder-se-ia dizer Versammlung [em alemão no original]), uma comunidade orgânica, num sentido não natural mas espiritual, que crê no progresso infinito do espírito pela liberdade". Tradução nossa. 
Ora, é na questão da língua, como um dos traços unificadores do homem, que Derrida se debruçará com extremosa atenção, em especial a palavra Zeichen, que significa signo e, paradoxalmente, monstro. Por que razão se interessa Derrida, num texto intitulado $A$ mão de Heidegger, pelo Geschlecht? Primeiro, pela imensa dificuldade da sua tradução, considerando-a como uma palavra sensível, crítica e nevrálgica; segundo, "para indicar o lugar irredutível da questão da humanidade (contra a animalidade), e de uma humanidade no qual o nome, como o lugar do nome da «coisa», se assim se pode dizer, permanece igualmente problemática como a da língua na qual ele se inscreve" (1990, 181). Portanto, é urgente ter em mente que, para Derrida - e afirmamos aqui igualmente a nossa posição ao lado do filósofo -, a diferença existente entre humanidade e animalidade permanece problemática, ou ainda não se poderá falar de uma diferença radical.

Para José Gil a palavra monstro terá sofrido um ligeiro desvio na sua etimologia, no que ela pretendia significar, tal como o phármakon apresentado por Derrida. Monstro ficou associado ao verbo latino mostrare e à tradução «mostrar» ou "até mesmo «por indicar com o olhar». Etimologicamente, contudo, mostrare significa muito menos «mostrar» um objecto do que «ensinar um determinado comportamento, prescrever a via a seguir»" (Benveniste em Gil, 1994, 77). Assim, de acordo com Gil e Émile Benveniste, monstro indica mais uma advertência, um sinal que anunciaria calamidades acontecidas ou por vir (o que na Idade Média era considerado como portenta) $(1994,25)$ e até mesmo representaria males ou mirabilia $(1994,32)$ da natureza ou doenças. Ora, Derrida, no seu texto, parece recuperar esse sentido, aproveitando, segundo ele, um dos sentidos menos conhecido:

É numa outra direcção que começarei a privilegiar aqui. Ela vai no sentido de um sentido menos conhecido, uma vez que em francês $a$ monstra [la monstre] (troca de género, de sexo ou de Geschlecht) tem o sentido poético-musical de um diagrama que mostra [montre] num pedaço de música o número de versos e o número de sílabas atribuídas ao poeta. Monstro [monstre] é mostrar, e uma monstra é uma mostra. (1990, 182. Itálico do autor). 
Embora de difícil tradução para português, esta relação linguística derrideana, é possível descobrir algumas semelhanças, por exemplo, com demonstrar - ou seja, dar provas de qualquer coisa, dar a ver, verificar a veracidade de um acto, um gesto, assinalar pelo exercício da repetição, é indicar ou criar, de certa maneira, um monstro. Mas há, na significação do filósofo, um sentido que, tal como em José Gil, aponta: o da prescrição e o da indicação. Diz-nos Derrida que, "[a] monstra, pois, prescreve os cortes de versos para uma melodia. O monstro ou a monstra, é aquilo que mostra para advertir ou para pôr em guarda. Antigamente a mostra, em francês, escrevia-se a monstra" (1990, 182-183). Mas como de signo, Zeichen, chegamos a monstro?

Derrida retoma a tradução do texto heideggeriano sobre o pensamento, Was heisst Denken?, e em particular uma estrofe de Hölderlin citada pelo filósofo alemão. Aí Zeichen é traduzido por monstro e é essa tradução que deu muito a pensar a Derrida. A tradução francesa dos versos segue deste modo: "Nós somos um monstro privado de sentido / Encontramo-nos fora da dor / E perdemos / Quase a língua para o estrangeiro" 16 . Nós, esse «nós» que conjuntamente somos enquanto membros do Geschlecht, da Menschlichkeit, somos monstros que mostramos, signos de prescrição, bem como indicadores, signos de apresentação, embora privados de sentido. Enquanto monstros que mostramos, nada mostramos, nada dizemos, nada apresentamos. Essa é a nossa monstruosidade: a monstruosidade da mostração.

Aquilo que muitas vezes se perde nas traduções parece ter ganho ali uma dimensão que o próprio Derrida não esperava. Ele próprio apresenta três virtudes decorrentes desse «erro» entre signo e monstro: 1) relembra a relação sugerida por Heidegger entre signo e mostração; 2) releva o espaçamento no próprio signo, da sua normalidade, que mostra, à situação em que ele nada mostra, que nada significa, anunciando a perda da língua; 3 ) coloca a questão (fundamental) do (o que é o) homem. 0 «nós» dos versos é o nós do Geschlecht; o traço corporal próprio do Geschlecht, disso que é comum a todos e que permite a ligação entre homens na criação da comunidade, é a mão e a sua relação à linguagem, à língua

16 Derrida, 1990, 183. "Nous sommes un monstre privé de sens / Nous sommes hors douleur / Et nous avons perdu / Presque la langue à l'étranger". 
e ao pensamento. ${ }^{17}$ "A mão: o próprio do homem enquanto monstro (Zeichen)" (Derrida, 1990: 185). Mas o que é a mão, ou melhor, o que é a mão de Heidegger?

Em Was heisst Denken? a mão oferece e recebe as mãos e as coisas, guarda, transporta, mas principalmente traça signos, indica, mostra, porque o homem é um signo/monstro (Zeichen). Todavia, o que mais intriga Derrida é o que é afirmado num seminário por Heidegger, posterior à Carta sobre o Humanismo, por volta de 1951-1952. Nesse seminário Heidegger profere o dito quase profético de que não pensamos ainda, que releva o problema da técnica, afirmando igualmente que o que distingue o Geschlecht humano de todas os outros Geschlecht, como o dos macacos, é a mão, monstruosidade própria do homem como ser de mostração. Mas se não pensamos, aquilo que o homem procura é aprender a pensar; e nesse gesto de humildade Heidegger traz a mão à presença. É que pensar "é talvez simplesmente da mesma ordem que trabalhar num cofre" $(1990,187)$. O que quer isto dizer afinal? Trata-se de se colocar na posição de aprendiz de uma profissão (Handwerk em alemão), de alguém que aprende a manusear certos utensílios e descobrir o lugar onde a essência de uma coisa encontra a essência do homem. Tornar o pensamento um Handwerk é manobrar o que é próprio do homem, no sentido de descortinar o sentido essencial das coisas e do próprio pensamento. Pensar é pôr à mão, para poder acolher, preender para com-preender. O próprio Heidegger no-lo diz, pensar ou o pensamento é um trabalho manual, um trabalho da mão, para a mão.

A razão de Heidegger ter escolhido a mão para poder pensar o pensamento, Derrida expõe-na a partir de três pontos: 1) O filósofo alemão lê e liga o pensamento relativamente a uma situação do corpo, do corpo do homem e do ser humano, o que para Derrida representa uma dimensão do Geschlecht enquanto sexo ou diferença sexual; pensar é uma maneira do Ser-aí em corpo, em carne; 2) Heidegger privilegia a mão no momento em que, relacionando o pensar a uma profissão de ensino, opõe uma actividade dirigida à utilidade, à utensilidade, face ao verdadeiro mano-

17 Relembremos parte do princípio do Elogio da mão: "Através delas o homem entra em contacto com o rigor do pensamento. Elas definem o bloco, impondo-lhe uma forma, um perfil e, na própria escrita, um estilo". Focillon, 2001, 107. 
brar, Hand-Werk (onde podemos escutar, pensamos por nossa parte, o carácter poiético do homem, a obra pela mão). Derrida chama mesmo a atenção de que em Hand-Werk, Heidegger apela-nos a pensar Werk como obra e Hand como mais do que agir, "[é] preciso pensar a mão. Mas não a podemos pensar como uma coisa, um estado, muito menos como objecto. A mão pensa antes de ser pensada, ela é pensamento, um pensamento, o pensamento" (1990, 190. Itálico do autor). O terceiro ponto toma contornos mais críticos do ponto de vista político-económico, pois alinha-se no discurso contra a técnica, a profissionalização e no que isso traz de mal para o homem. Assim a mão vira-se para o lado artesanal, mais próximo da terra, do pensamento da clareira, da floresta, do barro.

Ora, este ponto, embora não parecendo, torna-se, para nós, no mais importante, projectando-se até à questão inicial. A mão, o ser da mão, vai para além de ser um órgão corporal de preensão, ou, como diz Derrida, "ela não é da ordem do preender conceptual" (1990, 191). A essência da mão não é somente a preensão que possibilita a compreensão, mas mais a carnação do dom do homem, o dom que dá, que doa qualquer coisa ao mundo, ao Outro, que é diferente da preensão e da doação do animal: "A mão do homem será pois uma coisa à parte não enquanto órgão separável mas porque diferente, dissemelhante (verschieden) de todos os outros órgãos de preensão (patas, pinças, garras); ela está distante de modo infinito (Unendlich) do abismo do seu ser (durch einen Abgrund des Wesens)" (1990, 194).

Se esse abismo, para Heidegger, é a palavra e o pensamento, nós acrescentamos o modo do homem poder apresentar-se e representar-se, como (n)a Arte, que se aproxima, senão mesmo se acopla, no pensamento de Derrida, ao que o filósofo chama de "dupla vocação da mão. (...), a vocação de mostrar ou a fazer signo (zeigen, Zeichen) e a dar ou a dar-se, numa palavra a monstruosidade do dom ou de quem se dá" (1990, 194. Itálico do autor). Se o Dasein, o Ser-aí, para Heidegger, não está/é presente-à-mão (Vorhandenheit, presence-at-hand) nem prontoà-mão (Zuhandenheit, ready-to-hand, readiness-to-hand), então recorre à mão para se apresentar, para se dar, se dirigir à presença dos outros. Do mesmo modo, tal como para Heidegger, a poesia e o pensamento são os mais elevados trabalhos e desígnios do homem, obras da mão, acrescentamos, igualmente, no mesmo gesto esse abismado e abismante poder 
do homem de apresentar(-se) e representar(-se), toda a arte elevada a semelhante desígnio, uma vez que a arte é um outro modo da presentificação do Ser-aí, do pensamento e do pensamento do Ser-aí.

\subsection{Do Lado de Brun}

Cremos que existe uma certa experiência da mão que desconhecemos no animal (o que não quer dizer que não exista; simplesmente não temos ainda acesso ao pensamento animal): a experiência do toque (como ele se reveste de intenção sensível no homem) e da carícia. Se Jean Brun afirma que preender e compreender implicam duas experiências construtoras de uma "Dimensão onde se move toda a existência humana; Dimensão que não representa apenas o quadro espacial [e temporal] das deslocações possíveis, mas que se desvenda, sobretudo, como o entreos-dois que toda a consciência do outro implica" $(1991,13)$, pensamos, pela nossa parte, que o toque e a carícia são mesmo as verdadeiras construtoras dessa Dimensão. Arriscamos dizer que o Geschlecht começa, exactamente, pelo toque e pela carícia, como aquilo que indaga o outro na proximidade ínfima, justo à mistura da carne, no desvanecimento do entre-os-dois. A mão humana guarda ainda a sua animalidade; e com ela o homem rasga, marca, traça o lugar da sua apresentação, da sua representação. É com a mão que o homem dá o seu rosto, uma vez que este, dando-se, marca a ausência da mão que já não o esconde mas guarda a distância, a mesma que derruba e aproxima o rosto do outro ao nosso.

Como pode existir Geschlecht, no sentido de Humanidade, se se insistir no intervalo do indivíduo, do individual? O meu rosto, a minha mão, sendo todos e todas, é nenhum e nenhuma. Essa é a lição de Robinson Crusoe de Michel Tournier. Preso às insistências tidas como maiores, às leis de intransigência, aos preconceitos de todos os géneros, só quando se liberta de todos os aguilhões e se dá a viver, lado a lado, abrindo-se à evasão do outro nele enquanto se dirige a Sexta-feira, só então nasce, existe, é com o mundo. A ética começa com um toque, tocar e ser tocado, na proximidade e na distância, mesmo sendo o outro um morto. E ser humano talvez comece por aí. Não se nasce humano, vamos sendo humanos; e o toque é o seu apelo. Em cada toque, em cada carícia, na 
sua específica singularidade dirigida a um corpo igualmente singular, deve procurar tocar e acariciar todos os corpos naquele que toca ${ }^{18}$.

A existência é, bem na verdade e concordando com Jean Brun, uma "dramática experiência do entre-os-dois" (1991, 123). Mas há um horizonte de possibilidades que por pouco extravasa essa distância, horizonte palpado pela mão, pois só ela é "ao mesmo tempo, tocante e tocada, pois é uma espécie de micro-organismo"(1991, 123), que porta toda a nossa vida para a sondagem do outro e da separação. A mão é não só a experiência da presença, mas o encontro material por excelência de duas singularidades que fragilizam a alteridade como oposto radical. É certo que, pelo toque, nesse envio, nessa evasão (para usar o termo que inaugura a existência em Michel Tournier) de um eu a um outro a alteridade se fragiliza, mas ao tocarmos somos igualmente tocados e no regresso transportamos um mundo incógnito e por decifrar que nos transforma. O drama, então, é o da superfície e como acertadamente disse Valéry, nada há de mais profundo que a pele, a superfície. "A mão que agarra visa compreender, a mão que toca espera chegar a conhecer" (1991, 129).

Por outro lado, a carícia é o instante que elimina, momentaneamente, a solidão eterna da existência, vai para além da superfície sem a ferir, sem rasgar a carne. A carícia, na verdade, é bem violenta, enche-se com a força do Acontecimento, choca contra e joga com o tempo e o espaço: "É, portanto, a espacialidade do mundo e dos seres que a carícia vem atacar, a fim de ultrapassar toda a separação física; a carícia procura libertar o outro peso de uma existência que o esmaga" (1991, 159). Onde a palavra não chega, onde a palavra já não toca, a carícia derruba toda a distância. A carícia: o rosto frente ao rosto, palavra a palavra, um poema que desarme e ame.

18 Não nos podemos alongar em toda a problemática do tocar, o que implicaria uma leitura atenta e profunda de Le toucher, Jean-Luc Nancy, de Derrida, bem como da obra do filósofo francês sobre o qual versa o livro. 


\section{Rostos e Mãos: Breves Notas Sobre Egon Schiele}

Pensando no drama da existência, na solidão de cada indivíduo, na impossibilidade de passar para além da superfície para, enfim, ver, tocar o outro, revelar o que de mais profundo pulsa em cada um, as vibrações das forças que nos percorrem, a arte dá provas de querer mergulhar e dar um rosto ao homem. O homem grita na arte; mas mais do que de morte o grito é de vida. Bacon tem toda essa força de desvelamento do rosto. Luta desesperada contra as forças e contra a morte arrancando-a do invisível. Contudo, não conseguimos evitar, quando vemos um quadro do pintor irlandês, pensar no expressionismo e um dos seus representantes austríacos, Egon Schiele.

O expressionismo foi uma procura da conquista do indivíduo, a captura do espírito do indivíduo, libertar pela boca toda a angústia, o medo, a frustração, a insatisfação. Mostrar, como ninguém antes ainda tinha mostrado, as forças que percorrem o homem, a força da emoção, da sensação, abertura ao interior. "O pintor transforma em obra a concepção sensível da sua experiência" (Marrucchi, 2006, 36), dizia Kirchner, líder do grupo Die Brücke. Essa experiência angustiante encontra-se expressa em Schiele, apresentando alguns traços que se poderiam ligar a Bacon. Repare-se, por exemplo, nos rostos, o vazio de alguns dos seus olhares, a solidão desses corpos encenados, o estranhíssimo contorcionismo dos corpos, desarticulando-se, comprimindo-se, desequilibrados, suspensos num vazio. Esse aspecto inatural dos corpos baconianos, com as suas torções, as suas linhas de fuga, a vibração dos seus devires-animais, ecoa, antes da sua pintura, nos corpos de Schiele. Há, obviamente, uma diferença de tempo pictural; os corpos de Bacon são apanhados, capturados no instante, dando a ver os eixos de força em acção; enquanto os corpos de Schiele congelados, suspensos no tempo da emoção, são uma só força, contida, encerrada pela linha.

Reparemos, por exemplo, no Auto-Retrato Nu de 1910 (vd. figura 1), olhemos para lá do narcisismo que tantas vezes Schiele foi acusado; o que lá está? O que nos diz aquele corpo, aquele rosto, aquelas mãos? O seu corpo, suspenso nesse fundo amarelado, envolto por uma neblina, uma aura branca, vê-se preso, empurrado, por uma qualquer força na qual as mãos se esforçam por impedir a aproximação. O corpo, indefeso 


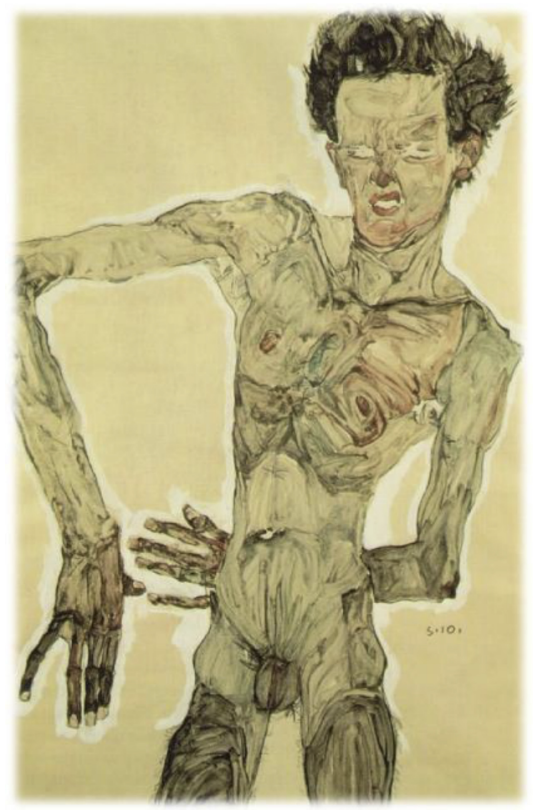

FIGURA 1: Egon Schiele, Auto-Retrato Nu, 1910.

na sua nudez, frágil na sua magreza, mostra sinais tensos do esforço, do combate. As mãos param o que vem, aquilo que o corpo parece não suportar no seu esgotamento, os músculos tensos, o rosto em sofrimento. Há uma torção do torso. O homem ainda não virou costas contra o objecto que o empurra, essa posição de último momento, de último recurso que antecede o desfalecimento. Esse corpo, cujas mãos e rosto bem mostram, indicam, para além da angústia, da fragilidade, o desvanecer, o dissipar - talvez essa aura, que rodeia a linha bem definida do corpo, nada mais seja do que o esfumar da força vital - do homem. Aquele rosto, aquelas mãos, pedem o nosso auxílio. Schiele descentra os corpos e estas fugas do centro permitem as ditas poses estranhas e movimentos bizarros, mas quanto às mãos, aos rostos? Serão conduzidos somente pelo descentramento do corpo em relação ao espectador, ou neles, nas mãos e nos rostos, se concentra, afinal, a expressividade? Se o corpo é o suporte da expressividade, será pois o suporte das mãos e do rosto. 


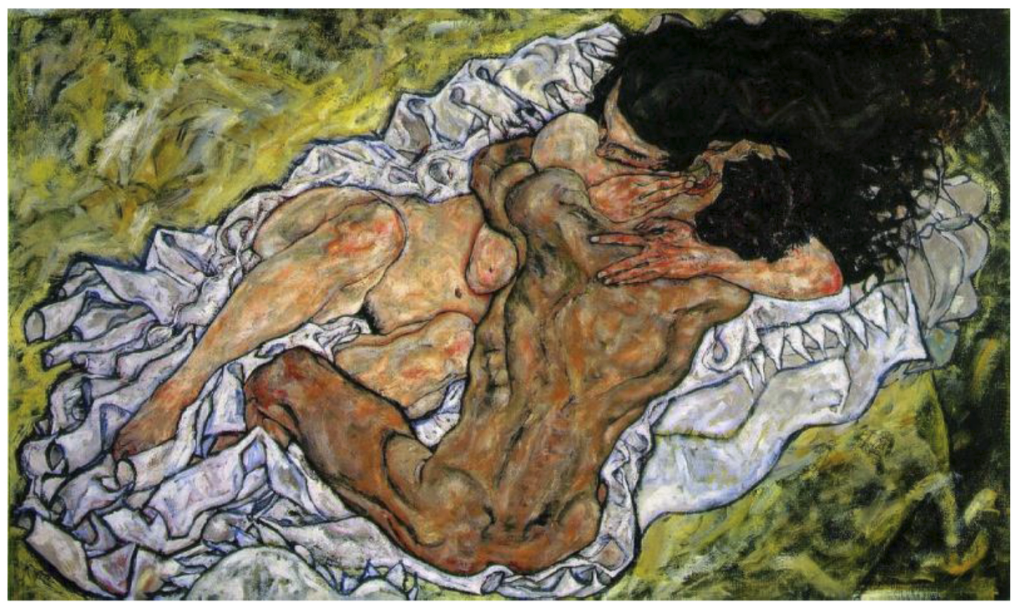

FIGURA 2: Egon Schiele, Enlace (Par Enlaçado II) de 1917.

De modo a terminar estas breves notas, gostaríamos de chamar, pela nossa parte, a atenção sobre um aspecto que passa por alguns dos desenhos de Schiele de conjunto, que nos parece deveras interessante. Quando os corpos se encontram emparelhados, quer nos desenhos mais eróticos, quer nos de tema amoroso, do casal de apaixonados, dos amantes, há como que um apaziguamento, um ligeiro alívio da emoção. Os corpos não estão inteiramente em paz, é certo, nunca estão, mas desvanecesse-se uma certa rudeza da expressão do rosto, a tensão das mãos denoda-se. Em alguns desenhos desaparecem mesmo as mãos por entre o corpo, como se o toque, a carícia, não no seu próprio corpo mas no do outro, libertasse, como diz Jean Brun, a existência do seu peso.

Duas mãos se repetem, como espelhadas. No famoso Enlace (Par Enlaçado II) de 1917 (figura 2) e no A Morte e a Rapariga de 1915/1916 (figura 3). No primeiro temos um abraço apaixonado entre dois amantes, quase sufocante, os seus corpos nus envolvidos intimamente parecem prolongar a desenvoltura dos lençóis, os seus rostos não precisam de ser vistos, a humanidade está ali vibrante. Mas repare-se na mão esquerda da mulher, no peculiar gesto que ampara o pescoço da figura masculina e repare-se, agora, na figura masculina do segundo quadro, a morte, um homem, amparando agora a cabeça da mulher e na resposta ao abraço 


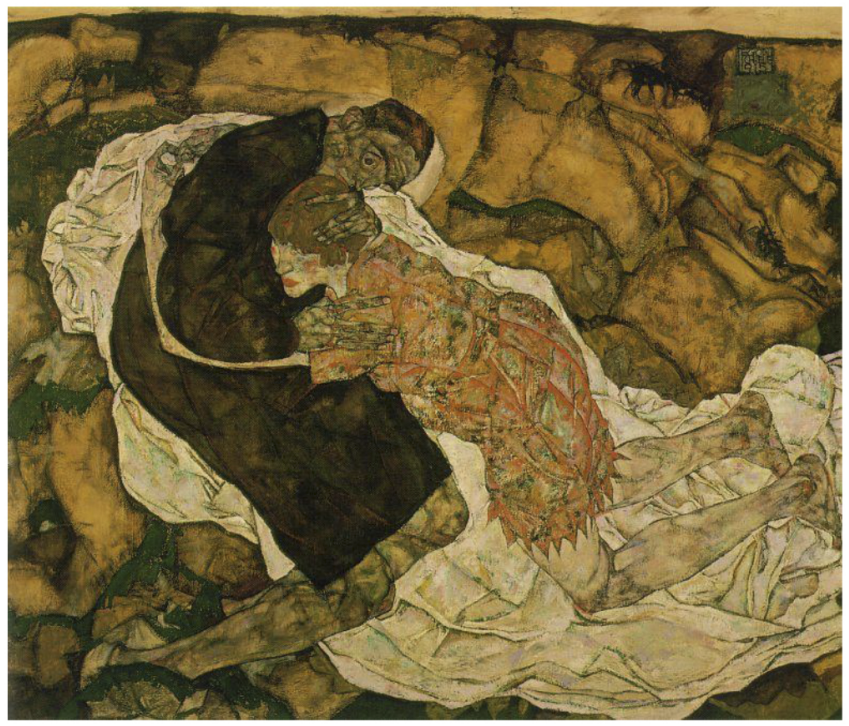

FIGURA 3: Egon Schiele, A Morte e a Rapariga de 1915/1916.

feminino desesperado, a mão direita do homem repete o da mulher do Enlace, num outro sentido, de afastamento. Os rostos, n'A Morte e a Rapariga, são já apresentados tristes, de olhar vazio, acabados. As mãos do homem dão a ver a amplitude da mão, acolhem e apartam, diríamos, como exemplificativos da preensão, compreendem a mulher. Todavia e esse é o toque que passa para lá da tela até nós -, a mulher, naquele elo entre dois dedos, somente aqueles dois dedos prendendo o homem, impedindo-o de partir, acaricia, a carícia.

Se podemos retirar qualquer conclusão deste texto que se disse, no seu princípio, retomar uma questão que não perdeu a sua pertinência, é a de que o homem é uma monstruosa produção desfigurada, uma superfície que se aprofunda, ou que toma uma depressão forçada pelo exterior, como o lugar onde a profundidade tem o seu espaço, lugar do infinito também ele produzido infinitamente. E que por fim, enfim, não tem fim. Tal como um pensamento, uma obra retomada por diversos pontos de vista, uma e outra vez, feito e refeito: produção infinita limitada pela morte singular de cada singular vida. Como afirmámos, o Humanismo não é só uma epistéme da Idade Moderna, também o desconstrucion- 
ismo é um humanismo. Deleuze, ao criticar Lévinas - esse humanista do homem - e ao criar ou remodelar conceitos como Corpo sem Órgãos, justamente a partir da morte do Homem, abre caminhos para a transformação do homem, essa produção inacabada, infinita, porque o desejo de o levar a outro lugar, ajudá-lo a encontrar outras ligações, talvez mais produtivas que as anteriores, é ainda trilhar o caminho proposto pelo defunto Humanismo, ou seja, o de indicar caminhos que evoluam a espécie humana tecnicamente e epistemicamente. Como uma vez disse Nietzsche, o homem é uma promessa; e essa promessa ainda está por cumprir e o Humanismo só desaparecerá com o último homem e o fim do Antropoceno.

\section{Referências}

Agamben, G., 2006, Profanações, Lisboa, Edições Cotovia, col. Ensaios.

Bergo, B., 2015, Emmanuel Levinas, The Stanford Encyclopedia of Philosophy (Summer 2015 Edition), Edward N. Zalta (ed.), http://plato. stanford.edu/archives/sum2015/entries/levinas/. Accessed 13 February 2016.

Brun, J., 1991, A mão e o espírito, Lisboa, Edições 70, col. Biblioteca de filosofia contemporânea.

Deleuze, G., Guattari, F., 1973, L'Anti-CEdipe, capitalisme et schizophrénie, Paris, Les Éditions de Minuit.

--- 1980, Mille Plateaux, capitalisme et schizophrénie, Paris, Les Éditions de Minuit.

Derrida, J., 1990, Heidegger et la question, de l'esprit et autres essais, Paris, Flammarion, col. Champs.

--- 1996, Le monolinguisme de l'autre ou la prothèse d'origine, Paris, Galilée.

Focillon, H., 2001, A Vida das Formas seguido de Elogio da mão, Lisboa, Edições 70, col. Arte e Comunicação.

Forte, A.J., 1989, Corpo de Ninguém, Lisboa, Hiena editora, col. Ideias e Atitudes.

Gil, J., 1994, Monstros, Lisboa, Quetzal Editores. 
--- 1997, Metamorfoses do Corpo, Lisboa, Relógio d'Água, col. Antropos, $2^{a}$ edição (1981).

--- 2001, Movimento total - O corpo e a dança, Lisboa, Relógio d'Água, col. Antropos.

Juarroz, R., 1998, Poesia Vertical, Porto, Campo das Letras, col. Campo da Poesia.

Lévinas, E., 1988, Totalidade e Infinito, Lisboa, Edições 70, col. Biblioteca de Filosofia Contemporânea.

Marin, L., 1993, Des pouvoirs de l'image, gloses, Paris, Éditions du Seuil, col. L'ordre philosophique.

Marrucchi, G., Belcari, R., 2006, A grande história da arte, século xx: cubismo, expressionismo e surrealismo, s.l., Público.

Tanizaki, J., 1999, Elogio da Sombra, Lisboa, Relógio d’Água, col. Antropos. 